\title{
ONLINE EDUCATION IN THE TIME OF COVID-19 CRISIS
}

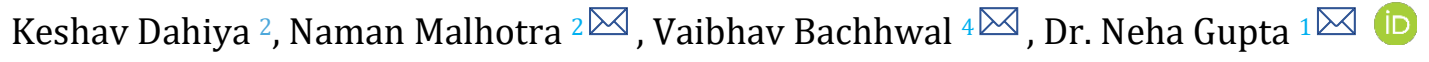 \\ 2,3, 4 Student, FCA, Manav Rachna International Institute of Research \& Studies, Faridabad \\ ${ }^{1}$ Faculty of Computer Applications, Manav Rachna International Institute of Research \& Studies, Faridabad
}

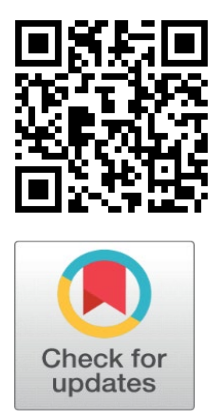

Received 21 August 2021

Accepted 05 September 2021

Published 30 September 2021

\section{CorrespondingAuthor}

Dr. Neha Gupta, neha.fca@mriu.edu.in DOI 10.29121/ijetmr.v8.i9.2021.1035

Funding: This research received no specific grant from any funding agency in the public, commercial, or not-for-profit sectors.

Copyright: (C) 2021 The Author(s). This is an open access article distributed under the terms of the Creative Commons Attribution License, which permits unrestricted use, distribution, and reproduction in any medium, provided the original author and source are credited.

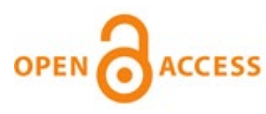

\section{ABSTRACT}

Prior to the pandemic, Indian educational institutions relied primarily on traditional means of instruction, like as face-to-face lectures in a classroom. Many academic units have already begun to mix learning throughout the pandemic, but many still maintain archaic traditions. The rapid outbreak of a lethal disease known as Covid19 due to the SARS-CoV-2 Corona Virus startled the whole world. It was labeled a pandemic by the World Health Organization. This has challenged the worldwide education system and prompted educators to move to an online teaching modality overnight. Many schools, which were previously reluctant to adapt their traditional approach to pedagogy, were unable to move totally to online instruction. The paper discusses the importance of online learning and of e-learning modalities analysis in times of crisis, including strengths, weaknesses, opportunities and challenges (SWOC). This article also highlights the emergence of EdTech startups during pandemics and provides ideas for academic institutions to tackle online learning issues.

Keywords: Self-Regulation Learning, COVID-19, Online Education

\section{INTRODUTION}

As the Internet has grown rapidly, some institutions and schools have provided online training as a potential solution to traditional individual training. Online education is a new area of learning, according to Denovan (2019), which combines remote education with personal education through computer connection. Communication is via computer and the World Wide Web with different social dynamics of learning and learners' engagement in the lessons. Bailey [Bailey et al. (2018)] recommend the following characteristics of online learning: (a) it gives a learning experience that is different from in conventional schoolrooms, (b) computer communication and World Wide Web communication, (c) varied learners' engagement in the classroom, (d) transform the social life of the learning environment and (e) decrease discrimination and prejudice.

Technological innovations, the Internet, live streaming, net meeting, etc. make higher education available and inexpensive for a huge number of students and those who could not study in a regular schoolroom [Bianco et al. (2016)]. As a result, online learning has become a vital component of an increasing curriculum for higher education institutions. The term online learning frequently involves Internet education, virtual learning and cyber learning. Distance contexts of teaching and learning can be acutely unique.

\footnotetext{
How to cite this article (APA): Dahiya, K. Malhotra, N. Bachhwal, V. and Gupta, N. (2021). Online Education in the Time of COVID19 Crisis. International Journal of Engineering Technologies and Management Research, 8(9), 70-77. doi: 
Its environment may be grouped into three fundamental types, fully Web-based, combined or combined, as well as universal courses with web-based supplements. Completely web-based classes govern the Internet, without direct communication, all courses are conducted in an online learning environment.

\subsection{FACTORS THAT LEADS TO THE SUCCESS OF ONLINE EDUCATION}

Below are the factors that leads to the success of online education system are:

\section{- Professional Education}

For a successful online education system, different strategies are needed. Technologies dealing with rapid changes isolate the nature of online instruction and makes professional development and mentorship important.

\section{- Communication}

It is a key feature to attain constructive online learning environment. If there will be an effective and regular communication between the instructor and the student then it will result in better communication and bring best out of students.

\section{- Self-Regulation Learning}

Online courses provide students with a certified means to expand their academic options while also assisting them in completing the difficult sector of education. The careful study of the system allows the student to choose whether or not the program is beneficial to them. The professor and course designer assist the students in comprehending the format of a course, which improves understanding and involvement. There should be clear guidelines and an easily traversed path for a well-designed course. This enables students to learn online in a medium which is not limited by time or location. Online learning can break down barriers caused via disability, poverty and other circumstances.

\section{- Flexibility}

Students are drawn to online education because of the benefits of flexibility. Learners can work from anywhere that suits their needs with online education.

\section{- Increases Accessibility}

As students' interest in online learning grows, a growing number of institutions are requiring them to satisfactorily finish an online course as a requirement for graduation.

\section{- Cost Effective}

According to Times Magazine "A hybrid method of education in major introductive courses can reduce the cost of education dramatically over the long term."

\subsection{POTENTIAL CHALLENGES OF ONLINE EDUCATION}

There are a slew of potential challenges and inconveniences that students may encounter while taking an online course.

\section{- Inability to Focus on Monitor}

It is extremely difficult to maintain sustained attention on a screen for an extended amount of time. When it comes to online learning, the likelihood of being diverted to social networking sites is substantially higher. As a result, it is critical for 
lecturers to make their sessions engaging and relevant in order to keep students attentive in class.

\section{- Technical Issues}

Furthermore, online classrooms that do not have a steady network connection for learners or lecturers can cause disruption in the student's learning. This could be detrimental to schooling.

\section{- Health Issues}

The fact that online education has increased many students' screen time is concerning. One of the most serious disadvantages is the growth in health problems, as well as the loss of sight. Physical issues have also been observed among the students.

\section{- Teacher Training}

In many circumstances, teachers lack the technical skills, as well as the resources and hardware needed to conduct online sessions for students. It will take time to provide the hardware and train the teachers.

\section{STUDENTS VIEWPOINT ON ONLINE EDUCATION}

According to a survey conducted in the month of November 2020, it was found that $80 \%$ of course content given in higher education institutions is delivered online [Bao et al. (2020)], students in this study were still hesitant to pursue online courses and grumbled about the ones they had completed. "Not only did the classes cost extra, but they also made me feel lost all the time," one participant said (Personal communication, November 11, 2020).

"The online session was pretty uninteresting, and I don't feel the instructor helped me very much," another participant said (Personal communication, November 11, 2020). It appears that these pupils have had negative experiences with online learning in the past. Despite the expanding literature regarding online education; studies related to its quality remain limited.

Some researchers examined the student's point of view on online education.

\section{INFLUENCE OF TECHNOLOGY AND EVOLUTION OF ONLINE COURSES}

Learning can be asynchronous, synchronous, or both in online education. Asynchronous learning refers to teaching and learning that occurs at different times [Cao et al. (2020)], whereas synchronous learning refers to teaching and learning that occurs at the same moment. They were both held on the web. In the late 20th century, the majority of programmes and classes used chatrooms and instant messaging and text-related services when online education was first popular. The participants may be selected by both sides. It was launched in 1972 with the @ symbol for emails and in 1991 for Internet connectivity the World Wide Web (WWW) was developed [Cohen et al. (1983)][Coleman et al. (2012)]. Both were the latest changes to online learning. The widespread usage of the internet has given birth to chances for the formation of online communities and groups. In online classes, emailing, conferencing, chatting, and sharing information via Google drive, Google Docs, Google Hangouts, Dropbox, Facebook, Twitter, and other platforms are common. 


\section{E-LEARNING PLATFORMS THAT GAIN SPOTLIGHT DURING COVID CRISIS}

\begin{tabular}{|c|c|c|c|}
\hline $\begin{array}{l}\text { Popular } \\
\text { Online } \\
\text { Education } \\
\text { Initiatives }\end{array}$ & Sponsor & $\begin{array}{l}\text { Year } \\
\text { founded }\end{array}$ & Fees \\
\hline Coursera & $\begin{array}{l}\text { Joint efforts by Princeton } \\
\text { University, Stanford } \\
\text { University, University of } \\
\text { California Berkeley, } \\
\text { University of Michigan- } \\
\text { Ann Arbor, \& University } \\
\text { of Pennsylvania }\end{array}$ & 2011 & Private \\
\hline eduMOOC & $\begin{array}{l}\text { University of Illinois } \\
\text { Springfield }\end{array}$ & 2011 & Free \\
\hline edX & $\begin{array}{l}\text { Harvard University \& } \\
\text { MIT }\end{array}$ & 2012 & $\begin{array}{l}\text { Non- } \\
\text { profit }\end{array}$ \\
\hline iTunes $\mathbf{U}$ & Apple Corporation & 2012 & $\begin{array}{l}\text { For- } \\
\text { profit }\end{array}$ \\
\hline $\begin{array}{l}\text { Khan } \\
\text { Academy }\end{array}$ & $\begin{array}{l}\text { Salman Khan } \quad \text { (Hedge } \\
\text { Fund manager) }\end{array}$ & 2007 & $\begin{array}{l}\text { Non- } \\
\text { profitabl } \\
\text { e }\end{array}$ \\
\hline Minerva & $\begin{array}{l}\text { Minerva project and } \\
\text { Keck Graduate Institute } \\
\text { (KIG). (Larry Summers, } \\
\text { former Harvard } \\
\text { University President \& } \\
\text { United States Secretary } \\
\text { of the Treasury, chaired } \\
\text { its first advisory board) }\end{array}$ & 2012 & Private \\
\hline MITx & $\begin{array}{l}\text { Joint efforts by Harvard } \\
\text { University and edx }\end{array}$ & 2001 & $\begin{array}{l}\text { Non- } \\
\text { profitabl } \\
\mathrm{e}\end{array}$ \\
\hline
\end{tabular}

\begin{tabular}{|c|c|c|c|}
\hline $\begin{array}{l}\text { Peer } 2 \text { Peer } \\
\text { University } \\
\text { (P2PU) }\end{array}$ & $\begin{array}{l}\text { Funding from the Hewlett } \\
\text { Foundation \& the } \\
\text { Shuttle-worth } \\
\text { Foundation, }\end{array}$ & 2009 & $\begin{array}{l}\text { Non- } \\
\text { profitabl } \\
\text { e }\end{array}$ \\
\hline Saylor & $\begin{array}{l}\text { Michael J. Saylor } \\
\text { (Chairman, CEO, \& } \\
\text { President of the business } \\
\text { intelligence company } \\
\text { Micro Strategy) }\end{array}$ & 2008 & $\begin{array}{l}\text { Non- } \\
\text { profitabl } \\
\text { e }\end{array}$ \\
\hline TED-Ed & Sapling Foundation & 1984 & $\begin{array}{l}\text { Private } \\
\text { Non- } \\
\text { profitabl } \\
\text { e }\end{array}$ \\
\hline Udacity & Sebastian Thrun & 2012 & $\begin{array}{l}\text { For- } \\
\text { profitabl } \\
\text { e }\end{array}$ \\
\hline Udemy & Eren Bali & $\begin{array}{l}\text { About } \\
2010\end{array}$ & $\begin{array}{l}\text { free; } \\
\text { some are } \\
\text { for a } \\
\text { tuition } \\
\text { fee }\end{array}$ \\
\hline $\begin{array}{l}\text { University } \\
\text { of the } \\
\text { People }\end{array}$ & $\begin{array}{l}\text { Shai Retief (educational } \\
\text { entrepreneur) }\end{array}$ & 2009 & N.A \\
\hline
\end{tabular}

\section{THE_COVID-19 PANDEMIC HAS CHANGED EDUCATION FOREVER. THIS IS HOW}

The COVID-19 ended in internationally closed schools. More than 1.2 billion kids are out of the classroom throughout. As a result, training has dramatically 
changed, as e-Learning differentiates, which enables instruction to be dealt with remotely and on a digital podium.

Research reveals that e-learning is shown to improve the acknowledgement of facts and takes less time to explain the changes created by covid-19.

\section{ONLINE EDUCATION DURING THE COVID-19 PANDEMIC}

On 11 March 2020, the World Health Organization (WHO), identified the Corona Virus Disease (COVID-19) as pandemic. Universities worldwide had to close their campuses and relocate their whole academic programmes online in the spring of 2020 [Denovan et al. (2019)]. Universities are not suitable for this transition from classroom to e-learning. Most universities lacked facilities and plans in the initial beginning. [Eysenbach (2005)].

The pandemic and the lockdowns have influenced the mind of people everywhere. Many students experience emotional distress and anxiety [Giustino et al. (2020)][Goodwin et al. (2016)]. Studies are sometimes limited by psychological concerns in their capacity to adapt to online instruction. In addition, the same access and expertise of digital technology is not available to all students. Even though these discrepancies were present, the COVID-19 epidemic revealed the digital gap [Hallgren et al. (2020)].

The pandemic pushed several organisations to change their workflow tactics rapidly and incorporate new technologies. In many situations, these organisations did not have enough time to think about the introduction and integration of the new strategy and the corresponding technology into their existing structure. There were no exceptions to universities all around the world. Bao may be the first to highlight how colleges move from school to online education due to the furious pandemic. In the course of COVID-19 pandemic usin empirical studies in India, Serbia and the USA researchers sought to grasp the point of view of students in online education.

In many countries, before the epidemic, there was a significant infrastructure for online education[Hall et al. (2020)]. Nevertheless, there was no university ready to go to online learning. Empirical studies revealed that students think they learn better than through online learning in actual classrooms[Harvey et al. (2018)]. Students lack assistance and access to libraries from their classmates in schools and laboratories[James et al. (2016)]. However, online learning encouraged students to continue their studies in the context of the pandemic[Kelders et al. (2012)]. In order to maintain the continuity of education to its students, universities now use creative strategies[Goodwin et al. (2016)].

There is a lack of research on how efficiently students can engage with professors and fellow students through a variety of on-line platforms. These difficulties were covered only by a few researchers. [Lesser and Nienhuis (2020)], for example, stated that pupils prefer to interact face to face with teachers, and[Bailey et al. (2018)] said there was a lack of trust in online assessment approaches for many teachers.

\section{HEALTH AND SOCIAL ISSUES}

The pandemic COVID-19 and the closure of university campuses impacted university students' mental health [Loprinzi (2013)]. Empirical studies conducted in Bangladesh, China, France, Greece, UK and USA reveal that a considerable number of students suffer from a variety of severe mental problems. Many students 
have experienced melancholy, worry, distress [Lumley et al. (2002)], and even thoughts of suicide[Loprinzi (2013)]. This condition affects the mental health of students modestly but continuously [Bao et al. (2020)]. The pandemic in general and their careers worry students. Many students find it difficult to focus on online education due to lack of desire and negative feelings. In research carried out shortly before COVID-19[Coleman et al. (2012)], it was found that the digital divide between urban and rural areas is common for pupils in rural areas to lack access to ICT. They also indicated that individuals who are financially destitute or living in rural areas often have limited access to digital technology. The regular access to digital technology necessitates on-line training. Students with limited access to digital technology, as well as those who are unfamiliar with them, have difficulty adapting to online education. They concluded that there was a digital divide, but it was worsened by the pandemic. In addition, some students reside in closed neighbourhoods and have trouble attending online classes [Cao et al. (2020)].

\section{CONCLUSION}

Online education provides students with a wonderful approach to broaden their chances and remain ambitious in the increasingly challenging world of education. Students willing to choose the higher education road through online courses must be responsible and self-motivated. Understanding one's study style and talents enables students to accurately decide whether online learning is appropriate. Instructors and course designers will also gain insight into the parts of a course that boost the comprehension of a student and its contribution to the course. Communication regarding constructive criticism, useful remarks and feedback from teachers to students is an important component of online training. Clear cut lines are other components of a well organised course, which is easy to navigate. All in all, online education enables learning to take place in a medium not limited to time or place. Online education helps break down barriers to disability, poverty and other variables.

\section{REFERENCES}

Armstrong, T., \& Bull, F. (2006). Development of the world health organization global physical activity questionnaire (GPAQ). Journal of Public Health, 14(2), 66-70. Retrieved from https://doi.org/10.1007/s10389-006-0024-X

Bailey, A. P., Hetrick, S. E., Rosenbaum, S., Purcell, R., \& Parker, A. G. (2018). Treating depression with physical activity in adolescents and young adults: A systematic review and meta-analysis of randomised controlled trials. Psychological Medicine, 48 (7), 1068-1083. Retrieved from https://doi.org/10.1017/S0033291717002653

Bao, Y., Sun, Y., Meng, S., Shi, J., \& Lu, L. (2020). 2019-nCoV epidemic: Address mental health care to empower society. The Lancet, 395(10224), e37-e38. Retrieved from https://doi.org/10.1016/S0140-6736(20)30309-3

Bianco, A., Spedicato, M., Petrucci, M., Messina, G., Thomas, E., Sahin, F. N., et al. (2016). A prospective analysis of the injury incidence of young male professional football players on artificial turf. Asian Journal of Sports Medicine, 7(1), Article e28425. Retrieved from https://doi.org/10.5812/asjsm.28425 
Cao, W., Fang, Z., Hou, G., Han, M., Xu, X., Dong, J., et al. (2020). The psychological impact of the COVID-19 epidemic on college students in China. Psychiatry Research, 287, 112934. Retrieved from https://doi.org/10.1016/j.psychres.2020.112934

Cohen, S., Kamarck, T., \& Mermelstein, R. (1983). A global measure of perceived stress. Journal of Health and Social Behavior, 24(4), 385-396. Retrieved from https://doi.org/10.2307/2136404

Coleman, K. J., Ngor, E., Reynolds, K., Quinn, V. P., Koebnick, C., Young, D. R., et al. (2012). Initial validation of an exercise "vital sign" in electronic medical records. Medicine \& Science in Sports \& Exercise, 44(11), 2071-2076. Retrieved from https://doi.org/10.1249/MSS.0b013e3182630ec1

Denovan, A., Dagnall, N., Dhingra, K., \& Grogan, S. (2019). Evaluating the perceived stress scale among UK university students: Implications for stress measurement and management. Studies in Higher Education, 44(1), 120133. [9] Elmer, T., Mepham, K., \& Stadtfeld, C. (2020). Students under lockdown: Assessing change in students' social networks and mental health during the COVID-19 crisis. PloS One, 15(7), Article e0236337. Retrieved from https://doi.org/10.1371/journal.pone.0236337

Eysenbach, G. (2005). The law of attrition. Journal of Medical Internet Research, 7(1), e11. Retrieved from https://doi.org/10.2196/jmir.1157 https://doi.org/10.2196/jmir.7.1.e11

Giustino, V., Parroco, A. M., Gennaro, A., Musumeci, G., Palma, A., \& Battaglia, G. (2020). Physical activity levels and related energy expenditure during COVID-19 quarantine among the Sicilian active population: A crosssectional online survey study. Sustainability, 12(11), 4356. [12] Glass, G. V., Peckham, P. D., \& Sanders, J. R. (1972). Consequences of failure to meet assumptions underlying the fixed effects analyses of variance and covariance. Review of Educational Research, 42(3), 237-288. Retrieved from https://doi.org/10.3390/su12114356

Goodwin, J., Behan, L., Kelly, P., McCarthy, K., \& Horgan, A. (2016). Help-seeking behaviors and mental well-being of first year undergraduate university students. Psychiatry Research, 246, 129-135. Retrieved from https://doi.org/10.1016/j.psychres.2016.09.015

Hallgren, M., Owen, N., Vancampfort, D., Smith, L., Dunstan, D. W., Andersson, G., et al. (2020). Associations of interruptions to leisure-time sedentary behaviour with symptoms of depression and anxiety. Translational Psychiatry, 10(1), 1-8. Retrieved from https://doi.org/10.1038/s41398-020-0810-1

Hall, G., Laddu, D. R., Phillips, S. A., Lavie, C. J., \& Arena, R. (2020). A tale of two pandemics: How will COVID-19 and global trends in physical inactivity and sedentary behavior affect one another? Progress in Cardiovascular Diseases, S0033-0620(20), 30077-3.

Harvey, S. B., Øverland, S., Hatch, S. L., Wessely, S., Mykletun, A., \& Hotopf, M. (2018). Exercise and the prevention of depression: Results of the HUNT cohort study. American Journal of Psychiatry, 175(1), 28-36. Higher education Statistics agency. Retrieved from https://www.hesa.ac.uk/news/16-01 2020/sb255-higher-education-student-statistics/numbers, Retrieved from https://doi.org/10.1176/appi.ajp.2017.16111223

(2020).

James, P., Weissman, J., Wolf, J., Mumford, K., Contant, C. K., Hwang, W. T., et al. (2016). Comparing GPS, log, survey, and accelerometry to measure physical 
activity. American Journal of Health Behavior, 40(1), 123-131. Retrieved from https://doi.org/10.5993/AJHB.40.1.14

Kelders, S. M., Kok, R. N., Ossebaard, H. C., \& Van Gemert-Pijnen, J. E. (2012). Persuasive system design does matter: A systematic review of adherence to web based interventions. Journal of Medical Internet Research, 14(6), e152. Retrieved from https://doi.org/10.2196/jmir.2104

Lesser, I. A., \& Nienhuis, C. P. (2020). The impact of COVID-19 on physical activity behavior and well-being of Canadians. International Journal of Environmental Research and Public Health, 17(11), 3899. Retrieved from https://doi.org/10.3390/ijerph17113899

Loprinzi, P. D. (2013). Objectively measured light and moderate-to-vigorous physical activity is associated with lower depression levels among older US adults. Aging \& Mental Health, 17(7), 801-805. Retrieved from https://doi.org/10.1080/13607863.2013.801066

Lumley, T., Diehr, P., Emerson, S., \& Chen, L. (2002). The importance of the normality assumption in large public health data sets. Annual Review of Public Health, 23(1),

151-169.

Retrieved

from

https://doi.org/10.1146/annurev.publhealth.23.100901.140546 